Красинский Владислав Вячеславович

доктор юридических наук, член Общественного

консультативного научно-методического Совета

при ЦИК России

Krasinsky Vladislav V., doctor of law,

the member of public scientifically-methodical

Council at the Central Electoral Commission of

Russian Federation

\title{
Решения Конституционного Суда Российской Федерации о противодействии религиозно-политическому экстремизму
}

Красинский B.B. Решения Конституционного Суда Российской Федерации о противодействии религиозно-политическому экстремизму // Современное право. 2013. № 6. С. 113-118; www.krasinskiy.ru

Аннотация: В статье анализируются правовые позиции Конституционного Суда Российской Федерации о противодействии религиозно-политическому экстремизму. Автор изучает положения законодательства и решения Конституционного Суда Российской Федерации о противодействии религиозно-политическому экстремизму.

Ключевые слова: религиозно-политический экстремизм, Конституционный Суд Российской Федерации, решения Конституционного Суда Российской Федерации, правовые позиции судей Конституционного Суда.

The article examines a legal positions of the Constitutional Court of the Russian Federation about counteraction to religiouspolitical extremism. The author studies the legal provisions and decisions of the Constitutional Court about counteraction to religiouspolitical extremism.

Key words: religiouspolitical extremism, Constitutional Court of the Russian Federation, decisions of the Constitutional Court of the Russian Federation, legal positions of judges of the Constitutional Court.

Взаимосвязанные правовые положения законодательства о противодействии религиозно-политическому экстремизму в Российской Федерации неоднократно становились предметом рассмотрения Конституционного Суда Российской Федерации. В рамках своей компетенции Конституционный Суд РФ по запросам уполномоченных субъектов проверял конституционность федеральных законов «Об общих принципах организации законодательных (представительных) и исполнительных органов государственной власти субъектов Российской Федерации», «О политических партиях», «О выборах депутатов Государственной Думы Федерального Собрания Российской Федерации», «О милиции», «О погребении и похоронном деле», подзаконных актов, примененных в конкретных делах, а также рассматривал жалобы на нарушение конституционных прав и свобод граждан. 
Решения Конституционного Суда РФ, связанные с противодействием религиозно-политическому экстремизму, можно классифицировать по предмету регулирования и по юридической силе проверяемых (оспариваемых) нормативных правовых актов.

В зависимости от предмета регулирования проверяемых (оспариваемых) нормативных правовых актов представляется возможным выделить:

- решения Конституционного Суда о конституционных полномочиях федеральных органов государственной власти и органов государственной власти субъектов РФ по защите основ конституционного строя, суверенитета, единства системы государственной власти и государственной целостности;

- решения Конституционного Суда, касающиеся статуса политических партий, принципов их организации и деятельности;

- решения Конституционного Суда по рассмотрению жалоб граждан на нарушение их конституционных прав действиями государственных органов и должностных лиц в области противодействия религиозно-политическому экстремизму и терроризму.

По юридической силе проверяемых (оспариваемых) нормативных правовых актов различаются решения Конституционного Суда по проверке конституционности федеральных законов и подзаконных актов, примененных в конкретных делах.

В Определении от 17 июня 2008 г. № 452-О-О по запросу Сахалинской областной Думы Конституционный Суд рассмотрел вопрос о разграничении предметов ведения и полномочий федеральных органов государственной власти и органов государственной власти субъектов РФ по противодействию терроризму и экстремизму ${ }^{1}$.

В соответствии с правовой позицией, выраженной Конституционным Судом Российской Федерации, «Конституция Российской Федерации непосредственно не определяет противодействие терроризму и экстремизму в качестве сферы ответственности какого-либо одного уровня публичной власти. Конституционно значимые цели данного направления деятельности Российской Федерации как демократического федеративного правового государства обусловливают необходимость осуществления системы правовых, организационных, экономических, воспитательно-идеологических и иных мер превентивного, пресекательного и восстановительного характера. Их реализация, в свою очередь, предполагает необходимость осуществления государственных полномочий как в сфере ведения Российской Федерации, так и в сфере совместного ведения Российской Федерации и субъектов Российской Федерации.

\footnotetext{
${ }^{1}$ Определение Конституционного Суда РФ от 17 июня 2008 г. N 452-О-О "Об отказе в принятии к рассмотрению запроса Сахалинской областной Думы о проверке конституционности подпункта "a" пункта 2 статьи 21 и подпункта 51.1 пункта 2 статьи 26.3 Федерального закона "Об общих принципах организации законодательных (представительных) и исполнительных органов государственной власти субъектов Российской Федерации"// Вестник Конституционного Суда РФ. 2009. № 1.
} 
Федеральный законодатель, устанавливая компетенционные, организационно-правовые, финансово-экономические и иные основы противодействия терроризму и экстремизму, вправе определять содержание и объем полномочий органов государственной власти субъектов Российской Федерации по противодействию терроризму и экстремизму».

К числу важнейших решений Конституционного Суда, касающихся проверки конституционности подзаконных актов по защите основ конституционного строя, суверенитета, единства системы государственной власти и государственной целостности, относится Постановление Конституционного Суда Российской Федерации от 31 июля 1995 г. № 10-П².

В нём оценивалась конституционность Указа Президента Российской Федерации от 30 ноября 1994 года № 2137 «О мероприятиях по восстановлению конституционной законности и правопорядка на территории Чеченской Республики», Указа Президента Российской Федерации от 9 декабря 1994 года № 2166 «О мерах по пресечению деятельности незаконных вооруженных формирований на территории Чеченской Республики и в зоне осетино-ингушского конфликта» и постановления Правительства Российской Федерации от 9 декабря 1994 года № 1360 «Об обеспечении государственной безопасности и территориальной целостности Российской Федерации, законности, прав и свобод граждан, разоружения незаконных вооруженных формирований на территории Чеченской Республики и прилегающих к ней регионов Северного Кавказа». По запросам Совета Федерации и группы депутатов Государственной Думы ФС РФ оспаривалась возможность использования Вооруженных Сил на территории РФ для защиты основ конституционного строя, суверенитета, единства системы государственной власти и государственной целостности.

В своем решении по данному делу Конституционный Суд подтвердил, что «Указ Президента Российской Федерации от 9 декабря 1994 года № 2166 «O мерах по пресечению деятельности незаконных вооруженных формирований на территории Чеченской Республики и в зоне осетиноингушского конфликта» принят в пределах конституционных полномочий Президента Российской Федерации, предусмотренных статьями 71 (пункт «М»), 78 (часть 4), 80 (часть 2), 82 (часть 1), 87 (часть 1), 90 (часть 3) и 114 (пункт «ж» части 1) Конституции Российской Федерации, и соответствует Конституции Российской Федерации.

2 Постановление Конституционного Суда РФ от 31 июля 1995 г. N 10-П "По делу о проверке конституционности Указа Президента Российской Федерации от 30 ноября 1994 года N 2137 "О мероприятиях по восстановлению конституционной законности и правопорядка на территории Чеченской Республики)", Указа Президента Российской Федерации от 9 декабря 1994 года N 2166 "О мерах по пресечению деятельности незаконных вооруженных формирований на территории Чеченской Республики и в зоне осетино-ингушского конфликта", постановления Правительства Российской Федерации от 9 декабря 1994 года N 1360 "Об обеспечении государственной безопасности и территориальной целостности Российской Федерации, законности, прав и свобод граждан, разоружения незаконных вооруженных формирований на территории Чеченской Республики и прилегающих к ней регионов Северного Кавказа", Указа Президента Российской Федерации от 2 ноября 1993 года N 1833 "Об Основных положениях военной доктрины Российской Федерации" 
Содержащиеся в постановлении Правительства Российской Федерации от 9 декабря 1994 года № 1360 «Об обеспечении государственной безопасности и территориальной целостности Российской Федерации, законности, прав и свобод граждан, разоружения незаконных вооруженных формирований на территории Чеченской Республики и прилегающих к ней регионов Северного Кавказа» положения о выдворении за пределы Чеченской Республики лиц, представляющих угрозу общественной безопасности и личной безопасности граждан, а также о лишении аккредитации журналистов, работающих в зоне вооруженного конфликта, признаны не соответствующими статьям 27 (часть 1), 29 (части 4 и 5), 55 (часть 3) и 56 Конституции Российской Федерации.

В формате противодействия религиозно-политическому экстремизму представляют интерес решения Конституционного Суда Российской Федерации, касающиеся статуса политических партий, принципов их организации и деятельности.

В Постановлении от 15 декабря 2004 года № 18-П «По делу о проверке конституционности пункта 3 статьи 9 Федерального закона «О политических партиях» в связи с запросом Коптевского районного суда города Москвы, жалобами общероссийской общественной политической организации «Православная партия России» и граждан И.В. Артемова и Д.А. Савина» ${ }^{3}$ Конституционный Суд РФ подтвердил законность ограничения создания политических партий по признакам национальной и религиозной принадлежности.

Конституционный Суд РФ отметил, что на современном этапе российское общество, в том числе политические партии и религиозные объединения, еще не приобрело прочный опыт демократического существования.

В этих условиях создание партий по религиозному признаку открыло бы путь к политизации религии и религиозных объединений, политическому фундаментализму и клерикализации партий, что в свою очередь повлекло бы отторжение религии как формы социальной идентичности и вытеснение ее из системы факторов, консолидирующих общество. Создание партий по национальному признаку могло бы привести к преобладанию в выборных органах власти представителей партий, отражающих интересы больших этнических групп в ущерб интересам малых этнических групп, и тем самым — к нарушению установленного Конституцией РФ принципа правового равенства независимо от национальной принадлежности.

По мнению Конституционного Суда, политические партии в России надконфессиональны и внеконффессиональны. В многонациональной и многоконфессиональной России - вследствие особенностей

3 Постановление Конституционного Суда РФ от 15 декабря 2004 г. N 18-П "По делу о проверке конституционности пункта 3 статьи 9 Федерального закона "О политических партиях" в связи с запросом Коптевского районного суда города Москвы, жалобами общероссийской общественной политической организации "Православная партия России" и граждан И.В. Артемова и Д.А. Савина"// Рос. газ. 2004. 24 декабря. 
функционирования ведущих вероучений (с одной стороны, православия как господствующего направления христианства, а с другой - мусульманства), их влияния на социальную жизнь, в том числе использования в политической идеологии, - такие понятия, как «христианский», «православный», «мусульманский», «русский», «татарский» и т. П., ассоциируются в общественном сознании скорее с конкретными конфессиями и отдельными нациями, чем с системой ценностей российского народа в целом. Поэтому Конституционный Суд РФ однозначно высказался против использования соответствующих слов в наименованиях политических партий.

Предметом рассмотрения Конституционного Суда РФ по жалобам Балтийской республиканской партии и Российской коммунистической рабочей партии являлся численный состав и территориальный масштаб деятельности политических партий.

В своем Постановлении от 1 февраля 2005 г. № 1-П по жалобе Балтийской республиканской партии Конституционный Суд указал, что «создание региональных и местных политических партий могло бы привести - принимая во внимание сложносоставной характер Российской Федерации к образованию множества региональных партийных систем, что чревато превращением формирующейся партийной системы в фактор ослабления развивающейся российской демократии, народовластия, федерализма, единства страны и тем самым - ослабления конституционных гарантий прав и свобод на всей территории Российской Федерации» ${ }^{4}$.

Конституционный Суд подтвердил, что законодательное регулирование, в соответствии с которым статус политической партии могут получить только общенациональные (общероссийские) общественные объединения, не только направлено на формирование в стране реальной многопартийности, на правовую институционализацию партий в качестве важного фактора становления гражданского общества и стимулирование образования крупных общенациональных партий, но и необходимо в целях защиты конституционных ценностей, прежде всего - обеспечения единства страны.

Численный состав и территориальный масштаб деятельности политических партий должен быть достаточным, чтобы они были способны выполнять свои уставные задачи в качестве общероссийских политических партий. Для формирования и выражения политической воли народа партия должна обладать значительной поддержкой в обществе. Такой поддержкой могут обладать только крупные и хорошо структурированные партии. Численность партии должна устанавливаться с учетом невозможности раздробления депутатского корпуса на множество мелких групп, чтобы

${ }^{4}$ Постановление Конституционного Суда РФ от 1 февраля 2005 г. N 1-П "По делу о проверке конституционности абзацев второго и третьего пункта 2 статьи 3 и пункта 6 статьи 47 Федерального закона "О политических партиях" в связи с жалобой общественно-политической организации "Балтийская республиканская партия" // С3 РФ. 2005. N 6. Ст. 491. 
обеспечить нормальное функционирование парламента, стабильность законодательной власти и конституционного строя в целом.

В Постановлении от 16 июля 2007 г. № 11-П по жалобе Российской коммунистической рабочей партии Конституционный Суд отметил, что «федеральный законодатель вправе устанавливать требования к численному составу политических партий, исходя из конкретно-исторических условий развития Российской Федерации; данные требования, предъявляемые к политическим партиям, могут меняться в ту или иную сторону, поскольку они не произвольны, а объективно обусловлены решаемыми в законодательном порядке задачами в сфере развития политической системы и обеспечения еe адекватности принципам конституционного строя Российской Федерации и не влекут отмену или умаление конституционного права граждан на объединение в политические партии или его несоразмерное ограничение».

Самостоятельный фрагмент составляют решения Конституционного Суда по рассмотрению жалоб граждан на нарушение их конституционных прав действиями государственных органов и должностных лиц в области противодействия религиозно-политическому экстремизму и терроризму.

В Постановлении Конституционного Суда РФ от 9 ноября 2009 г. № 16-П по жалобе гражданина В.3. Измайлова рассматривались конституционность и объективность оснований исключения избирательным объединением отдельных кандидатов из зарегистрированного списка. Конституционный Суд РФ пришел к выводу, что в случае осуществления кандидатом, включенным в список кандидатов, призывов к совершению экстремистских действий, разжигания социальной, национальной или религиозной розни, пропаганды и публичной демонстрации нацистской атрибутики или символики, либо установления в отношении такого кандидата фактов осуществления экстремистской деятельности до приобретения им статуса кандидата избирательное объединение вправе по собственной инициативе исключить таких кандидатов из зарегистрированного списка.

В Определении от 21 декабря 2004 г. № 411-О «Об отказе в принятии к рассмотрению жалобы гражданина Одиянкова Ю.Г. на нарушение его конституционных прав положениями пункта 9 статьи 18, пунктов 7 и 8 статьи 64 Федерального закона «О выборах депутатов Государственной Думы Федерального Собрания Российской Федерации» и пункта 28 статьи 10 Закона РСФСР «О милиции» Конституционный Суд подтвердил конституционность правовых положений, предусматривающих право избирательных комиссий обращаться в правоохранительные органы с представлениями о пресечении нарушений правил предвыборной агитации, и обязанность правоохранительных органов принимать меры по пресечению таких нарушений.

В области противодействия религиозно-политическому экстремизму в Российской Федерации заслуживает внимания Постановление Конституционного Суда от 28 июня 2007 г. № 8-П «По делу о проверке 
конституционности статьи 14.1 Федерального закона «О погребении и похоронном деле» и Положения о погребении лиц, смерть которых наступила в результате пресечения совершенного ими террористического акта, в связи с жалобой граждан К.И. Гузиева и Е.Х.Кармовой» ${ }^{5}$.

Согласно сформулированной в данном Постановлении правовой позиции Конституционного Суда, «интересы пресечения терроризма, его общей и специальной превенции, ликвидации последствий террористических актов, сопряженных с возможностью массовых беспорядков, столкновений различных этнических групп, эксцессов между родственниками лиц, причастных к террористическим актам, населением и правоохранительными органами, угрозой жизни и здоровью людей, могут обусловливать в определенных конкретно-исторических условиях установление особого правового регулирования погребения лиц, уголовное преследование в отношении которых в связи с участием в террористической деятельности прекращено из-за их смерти, наступившей в результате пресечения террористического акта.

Захоронение лица, принимавшего участие в террористическом акте, в непосредственной близости от могил жертв его действий, совершение обрядов захоронения и поминовения, с одной стороны, служат пропаганде идей террора, а с другой - оскорбляют чувства родственников жертв этого акта и создают предпосылки для нагнетания межнациональной и религиозной розни. Выдача родственникам для захоронения тел лиц, смерть которых наступила в результате совершенного ими террористического акта, способна создать угрозу общественному порядку, правам и законным интересам других лиц, их безопасности, в том числе привести к разжиганию ненависти, спровоцировать акты вандализма, насильственные действия, массовые беспорядки и столкновения, что может повлечь за собой новые жертвы, а места захоронений участников террористических актов могут стать местами культового поклонения отдельных экстремистски настроенных лиц, будут использоваться ими в качестве средства пропаганды идеологии терроризма и вовлечения в террористическую деятельность.

При таких обстоятельствах федеральный законодатель вправе ввести особый порядок погребения лиц, чья смерть наступила в результате пресечения террористического акта, участниками которого они являлись».

Таким образом, анализ решений Конституционного Суда РФ о противодействии религиозно-политическому экстремизму свидетельствует о выработке системы доктринальных взглядов судей КС РФ, направленной на предупреждение и пресечение экстремистских проявлений, в т.ч. в политической и религиозно-идеологической сфере.

К числу таких доктринальных взглядов относятся:

5 Постановление Конституционного Суда РФ от 28 июня 2007 г. N 8-П "По делу о проверке конституционности статьи 14.1 Федерального закона "О погребении и похоронном деле" и Положения о погребении лиц, смерть которых наступила в результате пресечения совершенного ими террористического акта, в связи с жалобой граждан К.И. Гузиева и Е.Х. Кармовой" // СЗ РФ. 2007. N 27. Ст. 3346. 
- право федерального законодателя устанавливать содержание и объем полномочий органов государственной власти субъектов Российской Федерации по противодействию терроризму и экстремизму;

- правомерность ограничения создания политических партий по признакам национальной и религиозной принадлежности;

- недопустимость создания региональных и местных политических партий;

- установление численности партии с учетом невозможности раздробления депутатского корпуса на множество мелких групп, чтобы обеспечить стабильность законодательной власти и конституционного строя в целом;

- правомерность исключения избирательным объединением отдельных кандидатов из зарегистрированного списка в связи с осуществлением экстремистской деятельности либо установлением в отношении таких кандидатов фактов осуществления экстремистской деятельности до приобретения ими статуса кандидата;

- правомерность правовых положений, предусматривающих право избирательных комиссий обращаться в правоохранительные органы с представлениями о пресечении нарушений правил предвыборной агитации, и обязанность правоохранительных органов принимать меры по пресечению таких нарушений;

- правомерность установления особого законодательного регулирования погребения лиц, смерть которых наступила в результате совершенного ими террористического акта, с учетом возможности массовых беспорядков, столкновений различных этнических групп, эксцессов между родственниками лиц, причастных к террористическим актам, населением и правоохранительными органами.

Конституционно-правовой смысл, выявленный Конституционным Судом Российской Федерации, является общеобязательным и исключает любое толкование проанализированных правовых позиций в правоприменительной практике. 